\title{
Tannins in Acacia cyanophylla Lindl. leaves : their effect on digestion by sheep fed alfalfa hay-based diets
}

\author{
H Ben Salem 1, A Nefzaoui ', H Abdouli 2, L Ben Salem 3 \\ 1INRAT, Laboratoire de Nutrition Animale, rue Hédi Karray, 2049 Ariana ; 'Ecole Supérieure d'Agriculture de \\ Mateur, 7049 Mateur ; 'Office de l'Elevage et des Pâturages, rue Alain Savary, 1002 Tunis, Tunisia
}

Acacia cyanophylla Lindl. is a leguminous fodder tree widely spread in Tunisia. It is characterised by a relative high crude protein content $(12-15 \%$ DM). It is reported in the literature (Reed et al, 1990, Anim Feed Sci Technol, 30, 39-50 ; Ben Salem and Nefzaoui, 1993 , 7th Meeting of the FAO European SubNetwork on Mediterranean Pastures and Fodder Crops, April 21-23, Crete-Greece, 118121) that nitrogen in acacia is poorly digested by animals, probably due to its condensed tannins. In this experiment, the effect of increasing amounts of acacia on intake and digestion by sheep was studied.

Five sheep fitted with a permanent rumen cannula were housed in individual crates and each received $700 \mathrm{~g} \mathrm{DM}$ of alfalfa hay and increasing amounts of air-dried Acacia cyanophylla leaves $(0,75,150,300 \mathrm{~g}$ DM or ad libitum). The five dietary treatments were tested according to a $5 \times 5$ Latin square design. Each diet was fed over 25-day periods in which 15 days were for dietary adaptation and 10 days for measurements. Diets were daily distributed in two equal meals, at 09.00 and at $17.00 \mathrm{~h}$. Digestibility was measured by total faecal collection. Fermentation parameters $(\mathrm{pH}$, ammonia nitrogen $\left(\mathrm{N}-\mathrm{NH}_{3}\right)$ ) in the rumen were measured on rumen liquid withdrawn for two consecutive days before $(0 \mathrm{~h}$ ) and 2, 4 and $8 \mathrm{~h}$ after feeding. Oat hay dry matter and soybean meal nitrogen degradabilities in the rumen were assessed by the nylon bag technique (Ørskov et al, 1980, Trop Anim Prod, 5, 195-213).

Acacia leaves had high crude protein (14\% DM), lignin (ADL, $16 \% D M$ ) and condensed tannins (4.5\% DM catechin equivalent) contents as compared to alfalfa hay (17.6 and 0.1 respectively). Fibre bound nitrogen (N-ADF) in acacia leaves is about $20 \%$ of total nitrogen. Acacia supply had no detrimental effect on diet intake. Voluntary intake of acacia was about $600 \mathrm{~g} \mathrm{DM}$. Increasing the amount of acacia to $300 \mathrm{~g}$ $\mathrm{DM} /$ day or more decreased organic matter (OM), crude protein (DP) and neutral detergent fibre (NDF) digestibilities. $\mathrm{N}-\mathrm{NH}_{3}$ concentration in rumen fluid was reduced when acacia was offered ad libitum. Cellulolytic activity decreased when the amount of acacia reached $300 \mathrm{~g} \mathrm{DM} /$ day. However, proteolytic activity decreased slightly only when acacia was offered ad libitum. Such a decrease was not high enough to lower the $\mathrm{N}-\mathrm{NH}_{3}$ concentration. Acacia voluntary intake was relatively high when sheep received a good quality roughage (alfalfa hay). This was not the case with poor quality roughages (straw) as reported by Reed et al (1990) and Ben Salem and Nefzaoui (1993). Therefore and in order to cover animal requirements, Acacia cyanophylla Lindl. should be associated with a good quality roughage. In this study, digestible organic matter intakes were improved by acacia supply (26 to $40 \mathrm{~g} / \mathrm{kg}$ LW 0.75 with $^{\circ} 0$ and $600 \mathrm{~g} \mathrm{DM}$ of acacia, respectively).

\begin{tabular}{|c|c|c|c|c|c|c|}
\hline Acacia (g DM) & 0 & 75 & 150 & 300 & $a d l i b$ & SEM \\
\hline Diet intake (g DM/kg LW0.75) & $45.1 \mathrm{c}$ & $47.3^{\mathrm{c}}$ & $51.3^{c}$ & $59.6^{b}$ & $79.2^{a}$ & 1.67 \\
\hline \multicolumn{7}{|l|}{ Diet digestibility (\%) } \\
\hline$O M$ & $66.5^{\mathrm{a}}$ & $66.3^{\mathrm{a}}$ & $67.3^{\mathrm{a}}$ & $60.4^{b}$ & $57.6^{\mathrm{b}}$ & 1.45 \\
\hline $\mathrm{CP}$ & $68.5^{\mathrm{a}}$ & $68.4^{a}$ & $66.1 \mathrm{ab}$ & $60.5^{b}$ & $54.0^{\circ}$ & 1.35 \\
\hline NDF & $56.3^{a}$ & $54.6^{\mathrm{ab}}$ & $56.6^{a}$ & $48.0^{\mathrm{b}}$ & $44.2^{\mathrm{b}}$ & 1.84 \\
\hline $\mathrm{N}-\mathrm{NH}_{3}(\mathrm{mg} / 100 \mathrm{ml})$ & $17.0^{\mathrm{ab}}$ & $18.0^{a}$ & $18.0^{a}$ & $16.2^{\mathrm{ab}}$ & $12.9^{b}$ & 0.93 \\
\hline \multicolumn{7}{|c|}{ In sacco degradability $(a+b, \%)$} \\
\hline dry matter & $76.2^{a}$ & $72.8^{b}$ & $70.0^{\mathrm{bc}}$ & $68.1^{c}$ & $63.6^{c}$ & 0.55 \\
\hline nitrogen & $99.9^{\mathrm{a}}$ & $97.7 \mathrm{ab}$ & $93.3^{\mathrm{ab}}$ & $93.1^{\text {ab }}$ & $91.2^{\mathrm{b}}$ & 1.38 \\
\hline
\end{tabular}

$a, b, c:$ data in the same line with different superscripts differ $(P<0.05)$ 